of mother-to-child transmission of syphilis: an evaluation from multi-country surveys and stakeholder interviews. PLoS Med. 2017;14:e1002473. https://doi.org/10.1371/journal.pmed.1002473

4. Workowski KA, Bolan GA; Centers for Disease Control and Prevention. Sexually transmitted diseases treatment guidelines, 2015. MMWR Recomm Rep. 2015;64(No. RR-3):1-137.

5. Centers for Disease Control and Prevention National Center for Health Statistics. Ambulatory health care data. 2019 Jul 3 [cited 2019 May 29]. https://www.cdc.gov/nchs/ahcd/index.htm

6. American Medical Association. Principles of the patient-centered medical home H-160.919. 2018 [cited 2019 May 29]. https://policysearch.ama-assn.org/policyfinder/detail/Principles $\% 20$ of $\% 20$ the $\% 20$ Patient-Centered $\% 20$ Medical $\% 20 \mathrm{Home} \% 20 \mathrm{H}-$ 160.919? uri=\%2FAMADoc\%2FHOD.xml-0-734.xml

7. McHugh M, Shi Y, Ramsay PP, Harvey JB, Casalino LP, Shortell SM, et al. Patient-centered medical home adoption: results from aligning forces for quality. Health Aff (Millwood). 2016;35:141-9. https://doi.org/10.1377/hlthaff.2015.0495

Address for correspondence: William S. Pearson, Centers for Disease Control and Prevention, 1600 Clifton Rd NE, Mailstop E-80, Atlanta, GA 30329-4027, USA; email: wpearson@cdc.gov

\section{Host Switching of Zoonotic Broad Fish Tapeworm (Dibothriocephalus latus) to Salmonids, Patagonia}

\author{
Roman Kuchta, Alžbeta Radačovská, \\ Eva Bazsalovicsová, Gustavo Viozzi, \\ Liliana Semenas, Marina Arbetman, \\ Tomáš Scholz
}

\begin{abstract}
Author affiliations: Biology Centre of the Czech Academy of Sciences, České Budějovice, Czech Republic (R. Kuchta,

T. Scholz); Institute of Parasitology, Slovak Academy of Sciences, Košice, Slovak Republic (A. Radačovská, E. Bazsalovicsová); Universidad Nacional del Comahue, San Carlos de Bariloche, Argentina (G. Viozzi, L. Semenas, M. Arbetman)
\end{abstract}

DOI: https://doi.org/10.3201/eid2511.190792

Diphyllobothriosis is a reemerging zoonotic disease because of global trade and increased popularity of eating raw fish. We present molecular evidence of host switching of a human-infecting broad fish tapeworm, Dibothriocephalus latus, and use of salmonids as intermediate or paratenic hosts and thus a source of human infection in South America.
$\mathrm{D}$ iphyllobothriosis is an emerging zoonotic disease caused by broad fish tapeworms. Except for the Pacific broad tapeworm (Adenocephalus pacificus), whose life cycle is completed in the sea, all species of the genus Dibothriocephalus (formerly in Diphyllobothrium) were limited to the freshwaters in the Northern Hemisphere (1). However, some of these tapeworms also were reported in the Southern Hemisphere, including South America, especially Patagonia, in the 20th century. Although the introduction routes of these human parasites remain unknown, their larvae (plerocercoids) have appeared in South America in nonnative but economically important salmonids, such as rainbow, brown, and brook trout $(2,3)$.

Several cases of diphyllobothriosis have been reported from South America, and plerocercoids of tapeworms identified as Dibothriocephalus latus and D. dendriticus have been reported in fish (Appendix Table 1, https://wwwnc. cdc.gov/EID/article/25/11/19-0792-App1.pdf). However, species identification was based almost exclusively on morphologic characteristics. Considering general uniformity, intraspecific variability, and shortage of species-specific morphologic traits (especially in plerocercoids), all previous reports of D. latus and $D$. dendriticus tapeworms from South America need verification (4). Reports concerning the most commercially important species of salmonids being infected with $D$. latus tapeworms are especially dubious because this species most likely uses only freshwater percid, esocid, and gadid fish as its second intermediate hosts in the Northern Hemisphere $(1,4)$.

Reliable identification of plerocercoids, which are the source of diphyllobothriosis, is crucial from the epidemiologic point of view because salmonids are of great economic value in South America as a food source for local populations, sport fishing, and exportation (5). We provide molecular evidence of second intermediate or paratenic host switching of human-infecting D. latus tapeworms in Patagonia, South America.

We found a total of 44 plerocercoids in 3 salmonid species: from Lake Gutiérrez, Rio Negro, Argentina (October 2017), rainbow trout (Oncorhynchus mykiss), of which $2 / 7$ fish examined were infected; brown trout (Salmo trutta), of which 3/4 were infected; and brook trout (Salvelinus fontinalis), of which 5/10 were infected; and from Lake Alicura, Neuquén, Argentina (April 2018), brown trout, of which $3 / 4$ were infected. Most plerocercoids were encysted in the body cavity, mainly among the pyloric ceca, and only a few were free in the muscle. We selected, photographed, and sequenced the partial cox 1 gene of 22 larvae in accordance with the procedure described by Wicht et al. (6). We also photodocumented morphologic vouchers (hologenophores) of sequenced specimens (Figure).

Our morphologic and molecular evaluation revealed the presence of $D$. dendriticus plerocercoids in 12 fish (8 


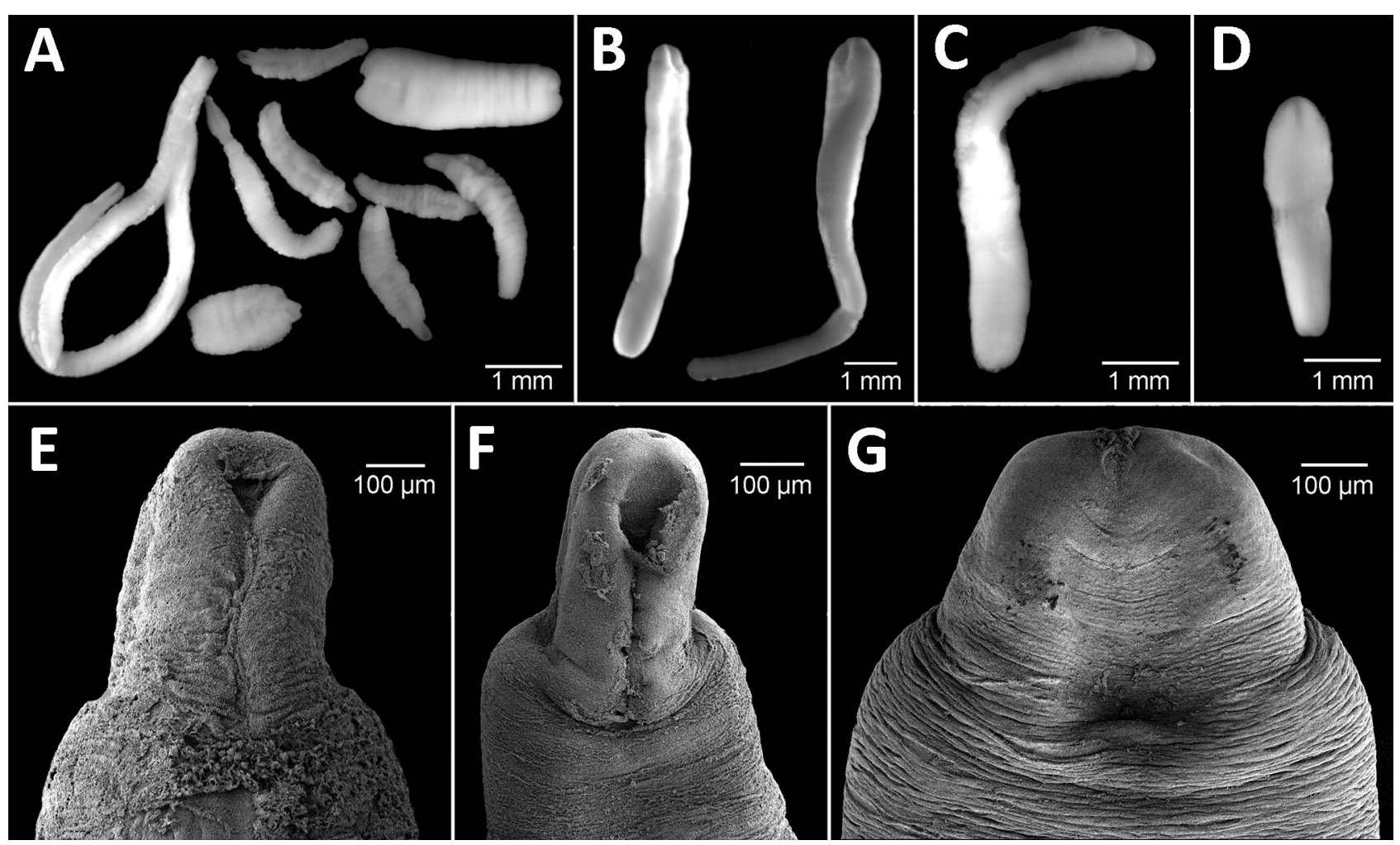

Figure. Microphotographs of Dibothriocephalus spp. plerocercoids from 3 salmonid species in Lago Gutiérrez, Patagonia, Argentina. A) $D$. dendriticus and $D$. latus plerocercoids from Oncorhynchus mykiss rainbow trout. B) $D$. latus plerocercoids from Salvelinus fontinalis brook trout. C) D. dendriticus plerocercoids from Salmo trutta brown trout. D) D. latus plerocercoids from $S$. trutta brown trout. E, F) D. dendriticus plerocercoids from O. mykiss rainbow trout. G) D. latus plerocercoids from $S$. fontinalis brook trout.

in $O$. mykiss rainbow trout, 2 in $S$. trutta brown trout, and 2 in $S$. fontinalis brook trout); their sequences were identical with those of $D$. dendriticus tapeworms from Chile (GenBank accession nos. AB623150 and AB623149). We also detected the presence of $D$. latus plerocercoids in 10 fish (1 in O. mykiss rainbow trout, 3 in S. trutta brown trout, and 6 in $S$. fontinalis brook trout); these sequences were identical with those of $D$. latus tapeworms from Italy (GenBank accession no GU997614) (Appendix Table 2).

D. dendriticus plerocercoids have been reported in $>50$ species of freshwater fish of 12 families, and salmonids represent the principal, most common fish hosts (7). In contrast, $D$. latus plerocercoids have never been confirmed reliably in salmonids in the Northern Hemisphere, where they occur in relatively few freshwater fish species, such as perch (Perca spp.), pike (Esox spp.), ruffe (Gymnocephalus cernua), burbot (Lota lota), and walleye (Sander spp.) (4), which are not present in South America. Therefore, D. latus tapeworms had to adapt to new second or paratenic intermediate hosts (i.e., salmonids) after their introduction to the Southern Hemisphere, even though salmonids are not suitable hosts in the Northern Hemisphere, where these tapeworms occurred originally $(1,4)$.
The origin of freshwater, human-infecting broad fish tapeworms in South America remains unknown. Salmonids were introduced to Chile (from Germany) and Argentina (from the United States) at the beginning of the 20th century as eggs or juveniles from a hatchery $(8,9)$. However, no evidence indicates that naturally infected salmonids were imported to South America. Introduction of adult tapeworms of Dibothriocephalus spp. through infected humans or dogs cannot be ruled out, nor can the introduction of $D$. dendriticus tapeworms by migratory birds $(1,4)$.

Our findings provide evidence of host switching of $D$. latus plerocercoids in Patagonia. Adaptation to new fish hosts might have serious epidemiologic consequences because of the economic importance of salmonids and their consumption by humans locally and abroad. Moreover, these introduced salmonids currently represent a substantial proportion of the total fish population in most of the lakes in the Andes region $(5,10)$. Therefore, parasitologic examination of fish before their exportation on ice is necessary to avoid emergence of new foci of human diphyllobothriosis.

This work was supported by the Czech Science Foundation (grant no. 19-28399X), the Institute of Parasitology, Biology Center of the Czech Academy of Sciences (institutional grant 
no. 60077344), the Slovak Research and Development Agency (grant no. APVV-15-0004), Slovak Grant Agency VEGA (grant no. 2/0134/17), the National Research Council of Argentina (grant no. PIP 2015-2017), and Universidad Nacional del Comahue (grant no. UNCoB/225).

\section{About the Author}

Dr. Kuchta is a researcher at the Institute of Parasitology in the Czech Academy of Sciences. His research interests include parasite biology, phylogeny, and molecular diagnosis of parasitic diseases, mainly diphyllobothriosis and sparganosis.

\section{References}

1. Kuchta R, Scholz T. Diphyllobothriidea. In: Caira JN, Jensen K, editors. Planetary biodiversity inventory (2008-2017): tapeworms from vertebrate bowels of the earth. Special publication no. 25 Lawrence (KS, USA): University of Kansas, Natural History Museum; 2017. p. 167-89.

2. Torres P, Franjola R, Pérez J, Auad S, Uherek F, Miranda JC, et al. Epidemiología de la difilobotriasis en la cuenca del Río Valdivia, Chile. Rev Saúde Pública. 1989;23:45-57. https://doi.org/10.1590/ S0034-89101989000100007

3. Revenga J, Semenas L. Difilobotriasis en salmónidos introducidos en el Parque y Reserva Nacional Nahuel Huapi Argentina: morfológia de plerocercoides. Arch Med Vet. 1991;23:157-63.
4. Scholz T, Kuchta R. Fish-borne, zoonotic cestodes (Diphyllobothrium and relatives) in cold climates: a never-ending story of neglected and (re)-emergent parasites. Food and Waterborne Parasitology. 2016;4:23-38. https://doi.org/10.1016/j.fawpar.2016.07.002

5. Soto D, Arismendi I, Gonzáles J, Sanzana J, Jara F, Jara C, et al. Southern Chile, trout and salmon country: invasion patterns and threats for native species. Rev Chil Hist Nat. 2006;79:97-117. https://doi.org/10.4067/S0716-078X2006000100009

6. Wicht B, Yanagida T, Scholz T, Ito A, Jiménez JA, Brabec J. Multiplex PCR for differential identification of broad tapeworms (Cestoda: Diphyllobothrium) infecting humans. J Clin Microbiol. 2010;48:3111-6. https://doi.org/10.1128/JCM.00445-10

7. Kuchta R, Brabec J, Kubáčková P, Scholz T. Tapeworm Diphyllobothrium dendriticum (Cestoda) - neglected or emerging human parasite? PLoS Negl Trop Dis. 2013;7:e2535. https://doi.org/ 10.1371/journal.pntd.0002535

8. Golusda P. Aclimatación y cultivo de especies salmonídeas en Chile. Bol Soc Biol Concepc. 1927;1:80-100.

9. Tulián E. Acclimatization of American fishes in Argentina. Bull Bureau Fish. 1910;28:3-20.

10. Fernández MV, Lallement M, Rechencq M, Vigliano PH, Sosnovsky A, Macchi PJ. Top predator fish assemblages in Northern Patagonia, Argentina. What factors regulate their patterns of distribution and abundance? Austral Ecol. 2018;43:651-62. https://doi.org/10.1111/aec.12610

Address for correspondence: Roman Kuchta, Biology Centre of the Czech Academy of Sciences, Institute of Parasitology, Branišovská 31, České Budějovice 370 05, Czech Republic; email: krtek@paru.cas.cz

\section{LETTERS}

\section{Achromobacter xylosoxidans Infections after Prostate Biopsies, France, 2014}

\author{
Lucie Amoureux, Julien Bador, \\ Catherine Neuwirth
}

Author affiliation: University Hospital of Dijon, Dijon, France

DOI: https://doi.org/10.3201/eid2511.161487

To the Editor: We read with interest the article by Haviari et al. concerning a health care-associated outbreak of Achromobacter xylosoxidans infections after prostate biopsies (1). Although noteworthy, the description lacks some data.

First, the isolates of Achromobacter cannot be referred to as $A$. xylosoxidans from just the method used in this study, API 20 NE mass spectrometry (bioMérieux, https:// www.biomerieux.com). Since 2012, a total of 18 species have been defined in the genus Achromobacter (2). Only multilocus sequence typing or sequencing $765 \mathrm{bp}$ of the housekeeping gene $n r d A$ enables the identification of the isolates to the species level (3). To date, in the few studies available, a great variety of species have been detected in clinical samples, with $A$. xylosoxidans the most predominant $(4,5)$. Correct identification of the isolates involved in all types of infection is necessary to help understand the epidemiology, pathogenicity, and resistance pattern of the various species.

Second, the antimicrobial drug resistance profiles are not given (except for ceftriaxone, which is an intrinsic resistance, and ofloxacin) but again are valuable epidemiologic data. This information might help in detecting the emergence of new cases in the unit or in other hospitals, as well as in discussing the therapeutic options.

Finally, all the bacteria recovered in the container belonged to environmental waterborne genera frequently encountered in wet sites in hospitals. As discussed by the authors, these microorganisms have been involved in contamination of antiseptic solutions containing quaternary ammonium compounds or chlorhexidine. Unfortunately, the authors did not mention which disinfectants were used in the biopsy room (for hands, sinks, surfaces, or containers) 